\title{
Susceptibility of Lenticels within the Stem Depression of Tomato Fruit to Bacterial Soft Rot
}

J. A. Bartz, Plant Pathology Department, University of Florida; D. J. Huber, S. L. Stahl, and J. H. Lee, Horticultural Sciences Department, University of Florida; D. Spiceland, Plant Pathology Department, University of Florida; and M. T. Elkahky, Plant Pathology Department, Faculty of Agriculture, Mansoura University, Mansoura, Egypt

\begin{abstract}
Bartz, J. A., Huber, D. J., Stahl, S. L., Lee, J. H., Spiceland, D., and Elkahky, M. T. 2016. Susceptibility of lenticels within the stem depression of tomato fruit to bacterial soft rot. Plant Dis. 100:1906-1909.

The postharvest development of bacterial soft rot in tomato fruit caused by Pectobacterium carotovorum is herein linked with inoculation of lenticel-like apertures located around the stem attachment. Stem scars misted with aqueous cell suspensions of $P$. carotovorum $\left(1 \times 10^{6} \mathrm{CFU} / \mathrm{ml}\right)$ or briefly $(5 \mathrm{~s})$ immersed in the suspension were likely to become infected during subsequent storage, with a disease incidence exceeding $70 \%$ within 7 days at $24^{\circ} \mathrm{C}$. Water soaking was initially observed beneath the fruit surface at the juncture of radial walls of endocarp tissues and a corky ring around the stem attachment. If fruit were swirled for $1 \mathrm{~min}$ in chlorine at $150 \mathrm{ppm}, \mathrm{pH}$ 6.5, within $5 \mathrm{~s}$ after inoculation, lesions did not occur. However, if the chlorine treatment was delayed by $120 \mathrm{~s}$, lesions occasionally

developed. A 60-min delay usually assured that decay would occur before fruit ripened (within 5 days). Delaying the chlorine wash by $18 \mathrm{~h}$, as would occur if commercial harvests were held overnight prior to packing operations, led to the same incidence of bacterial soft rot as observed among control fruit. Inoculation of fruit with attached stems did not lead to as much decay during storage compared with stemless fruit, suggesting that an intact calyx physically reduced lenticel exposure to external aqueous cell suspensions. Tomato fruit exposed to uncontrolled free moisture during or shortly after harvest have a high potential for postharvest decays and the likely site for infection development is the area surrounding the stem attachment.
\end{abstract}

Postharvest decay losses of fresh-market tomato (Solanum esculentum) often become extensive when harvests occur at a time when the crop is exposed to high rainfall, dew, fog, or conditions associated with reduced transpiration (Bartz et al. 2015a). Factors partially responsible for decay following "wet harvests" include an increased tendency for fruit to develop surface cracks prior to harvest and to be bruised or have surface injuries during harvest. Such fruit are called "soft" by growers. Additionally, free water on fruit surfaces at the time of harvest aids in the dispersal of pathogens and inoculation of wounds. Lesions developing on such fruit are often internal, beginning under or beside a stem scar. In a representative box of fruit sampled from a shipment rejected by a receiver, $88 \%$ of the lesions were either internal or associated with the stem scar (Bartz 1980). Packer mismanagement of the dump-tank or flume system was believed to contribute to the product loss. This lesion location was consistent with an infiltration of stem scar tissues by an aqueous cell suspension of bacteria (Bartz and Showalter 1981). If the stem scars were infiltrated by an aqueous cell suspension of Pectobacterium carotovorum (Jones 1901) Waldee 1945 emend. Hauben et al. 1998 emend. Gardan et al. 2003, such that fruit increased in weight by $\geq 0.1 \mathrm{~g}$, up to $100 \%$ of the fruit decayed during subsequent storage. By contrast, a decay incidence of only 5 to $15 \%$ occurred when the fruit weight increase was $<0.1 \mathrm{~g}$ (Bartz 1981).

Bacteria may internalize through stem scar structures before harvest and handling. Samish and Etinger-Tulczynska (1963) reported that a red-pigmented bacterium (Serratia marscens) applied to the calyx surface was subsequently isolated from internal fruit tissues several days later. Because the fruit were still attached to the plant, this internalization did not involve harvest damage. Wingard (1924) observed the development of bacterial soft rot on $62.5 \%$ of tomato still attached to plants after fruit were inoculated with "pieces of decayed

Corresponding author: J. A. Bartz; E-mail: softbart@ufl.edu

Accepted for publication 3 May 2016.

http://dx.doi.org/10.1094/PDIS-02-16-0173-RE

(C) 2016 The American Phytopathological Society fruit to their unpunctured surfaces." Lesions on $80 \%$ of the fruit began at the stem-fruit juncture. Further, Wingard (1924) noted that cultures of soft rot bacteria applied to uninjured fruit surfaces failed to initiate lesions within 9 days whereas, with wounded fruit, soft rot lesions were observed within 2 to 6 days. A review of internalization of Salmonella enterica by tomato fruit detailed evidence that cells of this pathogen survived better and were more resilient to aqueous chlorine solutions if allowed to dry on stem scars as compared with the smooth surface of fruit (Bartz et al. 2015a, b). The applications of suspensions of Salmonella spp. did not always include conditions expected to cause an infiltration of tissues by aqueous cell suspensions of bacteria such as reported by Bartz and Showalter (1981).

Lesion development within stem scars has been linked with other postharvest decays of tomato fruit. Pritchard and Porte (1923) noted that watery rot (now called sour rot) among commercially shipped fruit resulted rom stem scar infections. Lesions were not common at wounds because commercial fruit are relatively free of wounds. Moreover, laboratory inoculations led to infections at both wounds and stem scars. Water congestion at wounds on surfaces of green tomato fruit led to progressive lesions following inoculation by Geotrichum candidum, whereas similar inoculation of noncongested tissues followed by high-humidity storage led to arrested necrosis (Bartz et al. 2015a) Pathways by which water could move into tomato fruit were revealed by treatment of fruit with dye solutions (nigrosin or aniline blue) (Bartz et al. 2015b). In one series of experiments, a mixture of aniline blue and cells of $S$. enterica were infiltrated into stem scars. Fruit were dissected and sections applied briefly to the surface of trypticase soy agar plates. Colonies formed on the medium in clusters around prints of the stem scar and surrounding shoulder tissues. These areas coincided with dye accumulation in the fruit, evidence that bacterial cells internalized along with the dye through stem scar tissues.

Gas exchange for tomato fruit has been shown to occur through apertures in the stem scar even prior to harvest. Clendenning (1948) postulated "massive" annular lenticel tissues surrounding the receptacle, an area which is loosely covered by the calyx. These lenticels were connected to large intercellular spaces that were associated with vascular tissues (Seaton and Gray 1936). Wax applied over these apertures caused green fruit to become hypoxic, not ripen, and deteriorate internally (Brooks 1937). Clendenning (1948) observed a similar 
response among developing fruit if wax had been applied to the base of the stem. Stahl et al. (2014) observed gas egress from distinct apertures within the stem scar of tomato fruit submerged in water and exposed to a vacuum. They concluded that specific structures, likely a type of lenticel, enabled bubbles to emerge through the fruit periderm. The bubbles were large and emerged persistently in comparison with small amounts of egress associated with other structures within the stem depression (Stahl et al. 2015). Coverage of both the large lenticular-like openings and the interaperture corky ring on green fruit with wax prevented normal ripening.

Lenticels have served as infection courts for postharvest decays of other commodities. For example, freshly harvested potato tubers are known to be potential infection courts for $P$. carotovorum when moisture persists on tuber surfaces (Ruehle 1940). Prolonged wetness on tuber surfaces leads to a proliferation of cells within lenticels, which exposes underlying tissues to infection (Smith and Ramsey 1947).

Herein, we explore the potential infection of tomato fruit by $P$. carotovorum through lenticels located within the stem scar. A suspension of India ink was used as a surrogate for an aqueous suspension of soft rot bacteria to prove that particulate matter of the size of soft rot bacteria would move through lenticels into fruit tissues. India ink as a surrogate for gram-negative bacteria has been used to evaluate suture closure after eye surgery (Taban et al. 2005). Lesion location was used to differentiate between infections initiated among stem attachment tissues as compared with wounds or developmental injuries such as cuticle or surface cracks. Inoculated stem scars were washed with chlorinated water at various intervals to evaluate how rapidly inoculation became irreversible. Fruit with attached receptacles (stem and calyx) were immersion inoculated to determine whether such structures protected against intrusion of inoculum. Inoculated fruit were stored with stem scar upward versus downward to determine whether fruit orientation affected incidence of soft rot by ostensibly trapping moisture within the stem depression or allowing inoculum to seep into the stem scar tissues.

\section{Materials and Methods}

General methods. Mature green fruit were donated by a repacker or were hand harvested from field plots of 'Amelia' tomato. The cultivar provided by the repacker was unknown and the fruit did not have attached stems. By contrast, hand-harvested fruit included those with and without stems. All fruit were stored at $15^{\circ} \mathrm{C}$ until used, unless indicated otherwise. Fruit ripeness varied from mature green to pink among the different experiments but was uniform at the beginning of each test.

Aqueous cell suspensions of $P$. carotovorum (Florida strain, SR-38) were produced from 24-h nutrient broth shake cultures that were centrifuged from the broth and suspended in sterile $0.1 \%$ peptone broth and diluted based on turbidity ( 0.3 optical density $=$ approximately $2 \times 10^{8} \mathrm{CFU} / \mathrm{ml}$ at $600 \mathrm{~nm}$ ) to $1 \times 10^{6} \mathrm{CFU} / \mathrm{ml}$. Dilute peptone broth was included to create favorable and standardized conditions for survival of the bacterial cells on fruit. Inoculation was by a 5-s immersion in the final suspension or by a mist of the suspension until droplets were observed in the stem depression. A set of noninoculated

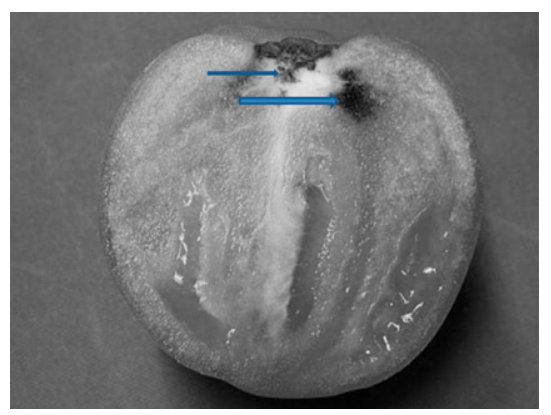

Fig. 1. Internal section of fruit infiltrated through stem scar with diluted India ink. Arrows point to accumulations of ink particles. fruit were treated similarly with sterile $0.1 \%$ peptone broth. Treated fruit were stored on a 24-fruit foam depression tray that was placed on wet paper towels in a Hefty Hi-Rise 32-quart (30.3 liter) latched storage container. The foam was impermeable to water. The lid rested on bars, which prevented an air-tight seal. Green fruit stored within the chamber ripened at rates similar to those on open trays. Humidity within the containers during incubation is described below.

After inoculation, fruit were handled randomly as would occur during harvest and allowed to drain for approximately $10 \mathrm{~min}$. Next, fruit were moved to depression trays in the storage containers. The lids were immediately latched in place. The containers were stored at $24^{\circ} \mathrm{C}$. Stored fruit were observed frequently and diseased fruit were removed as needed to prevent secondary spread. Each treatment comprised three replications of 5 to 10 fruit, depending on the experiment, and was repeated two to four times. Disease incidence at indicated storage intervals was either averaged for each treatment with an Excel program or evaluated by Proc GLM of SAS (version 9.4; SAS Institute Inc., Cary, NC). If treatment means included 0 values, square root of percentage plus 0.5 transformations were applied.

Affirmation that stem scar lenticels allow penetration of aqueous suspensions of gram-negative bacteria. Fruit were infiltrated with a $10 \%(\mathrm{vol} / \mathrm{vol})$ dilution of India ink in deionized water, as described (Bartz 1999). The size of the carbon particles in the ink was evaluated by filtering a $10 \%$ dilution of ink through a $0.22-\mu \mathrm{m}$ filter. The latter is used for filter-sterilizing fluids such as water (Sterlitech Corporation 2015). Ink movement into fruit tissues over time was observed in water-congested stem scars as defined by Johnson (1947). Water congestion was achieved by treating tomato fruit submerged in water with an air pressure that was equivalent to an immersion depth of $152 \mathrm{~cm}$ for $2 \mathrm{~min}$. Next, tomato were removed from the water, the stem depression was drained, and diluted India ink was added to the depression. Movement of ink into the tissues was timed. Fruit were sliced in half to reveal deposits of ink particles within internal tissues.

Determination that annular lenticels are infection courts for $\boldsymbol{P}$. carotovorum. Mature green to light pink tomato fruit were inoculated and incubated as described. Lesion location and incidence were recorded. In one set of experiments, fruit were mist-inoculated and placed on foam, fruit-depression trays with their stem depressions upward or downward to determine whether fruit orientation affected decay development.

Estimation of the duration of contact of stem scar tissues with inoculum required for development of bacterial soft rot. Fruit inoculated by brief immersion were washed for $1 \mathrm{~min}$ in a chlorine bath such as used in commercial packinghouses (FDACS 2011). The interval between inoculation and wash treatment varied from 1 to $18 \mathrm{~h}$ in an evaluation of the probable effect of stem scar inoculation on packinghouse operations. The shortest interval would represent harvest, transport from field to packinghouse, and immediate washing and packing of the fruit. The longest would represent holding the fruit

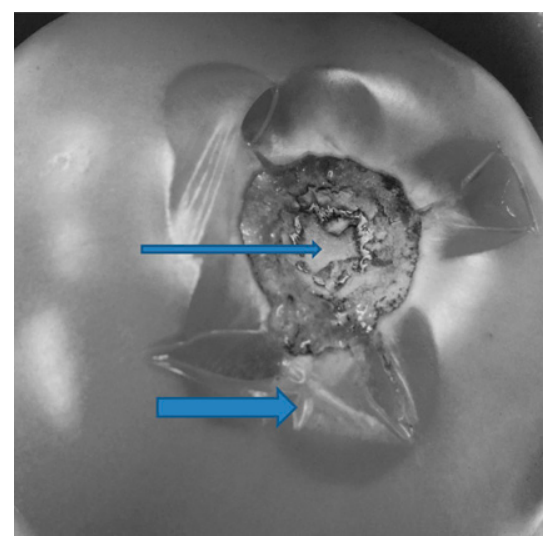

Fig. 2. Typical lesion associated with stem scar of inoculated tomato fruit, with small arrow indicating sound columella and large arrow directed to soft rot lesion. 
overnight between harvest and packing. In a second series of experiments, inoculated fruit were washed in the chlorine bath within $5,10,120$, or $3,600 \mathrm{~s}$ in an evaluation of how rapidly cells of $P$. carotovorum penetrated into lenticels and were no longer exposed to external sanitizing baths.

The effect of relative humidity (RH) in a storage chamber was evaluated by incubating inoculated fruit over wet paper towels, wet paper towels for $24 \mathrm{~h}$ followed by further incubation over dry paper towels, and incubation over dry paper towels. The RH within each storage container was recorded with a Watchdog Data Logger; Spectrum Technologies Model 250. Each latched chamber contained 15 fruit arrayed in three 5-fruit replicates.

Table 1. Incidence of bacterial soft rot among green tomato fruit after storage for 7 days at $24^{\circ} \mathrm{C}^{\mathrm{x}}$

\begin{tabular}{|c|c|c|}
\hline Treatments $^{y}$ & $\begin{array}{l}\text { Fruit with bacterial } \\
\text { soft rot }(\%)^{\mathrm{z}}\end{array}$ & $\begin{array}{l}\text { Diseased fruit with } \\
\text { lesions at stem scar (\% }\end{array}$ \\
\hline Control & $75.6 \mathrm{~A}$ & 91 \\
\hline $\begin{array}{l}\text { Chlorine wash at } 1 \mathrm{~h} \\
\text { postinoculation }\end{array}$ & $40.0 \mathrm{~B}$ & 100 \\
\hline $\begin{array}{l}\text { Chlorine wash at } 4 \mathrm{~h} \\
\text { postinoculation }\end{array}$ & $46.7 \mathrm{~B}$ & 100 \\
\hline $\begin{array}{l}\text { Chlorine wash at } 18 \mathrm{~h} \\
\text { postinoculation }\end{array}$ & $73.3 \mathrm{~A}$ & 88 \\
\hline
\end{tabular}

${ }^{x}$ Fruit were inoculated by a 5-s immersion in an aqueous cell suspension of Pectobacterium carotovorum containing $1 \times 10^{6} \mathrm{CFU} / \mathrm{ml}$; data are averages of three separate experiments.

${ }^{\mathrm{y}}$ Chlorine wash $=$ fruit swirled in chlorine $(\mathrm{pH} 6.5)$ at $150 \mathrm{ppm}$ for $1 \mathrm{~min}$ and then wiped dry.

${ }^{\mathrm{z}}$ Values not followed by the same letter were different at $\operatorname{Pr}<0.05$.

Table 2. Incidence of bacterial soft rot among tomato fruit after 5 days storage at $24^{\circ} \mathrm{C}$ as affected by duration between inoculation (immersion in Pectobacterium carotovorum at $1 \times 10^{6} \mathrm{CFU} / \mathrm{ml}$ for $5 \mathrm{~s}$ ) and chlorine-wash treatment $\mathrm{t}^{\mathrm{y}}$

\begin{tabular}{lc}
\hline Treatment & With lesions $(\boldsymbol{\%})^{\mathbf{z}}$ \\
\hline Control & $100 \mathrm{~A}$ \\
Wash at $60 \mathrm{~min}$ & $70.8 \mathrm{~B}$ \\
Wash at $2 \mathrm{~min}$ & $5.0 \mathrm{C}$ \\
Wash at $10 \mathrm{~s}$ & $1.7 \mathrm{C}$ \\
Wash at $5 \mathrm{~s}$ & $0.0 \mathrm{C}$ \\
\hline
\end{tabular}

$\mathrm{y}$ Treatment consisted of swirling for $1 \mathrm{~min}$ in chlorine $(\mathrm{pH}=6.5)$ at $150 \mathrm{ppm}$ and then wiping dry.

${ }^{\mathrm{z}}$ Averages of four separate experiments. Values not followed by the same letter were different at $P<0.05$.
Estimation of the effect of coverage of the stem depression lenticels by a calyx on decay development. Mature-green Amelia fruit with or without stems were dip inoculated and then stored to determine whether a calyx covering the stem depression and its lenticels would protect against inoculation or bacterial internalization during the treatments described.

\section{Results}

Confirmation that lenticels allow penetration of particulate matter the size of gram-negative bacteria. India ink filtered through a $0.22-\mu \mathrm{m}$ filter was completely devoid of color. By contrast, ink penetrated through lenticels in a tomato stem scar and was observed in tissues below the lenticels (Fig. 1). Thus, lenticel openings would not exclude particulate matter of the size of gram-negative bacteria. With water-congested stem scars, India ink was observed flowing into lenticels within $5 \mathrm{~s}$ after application of diluted ink onto the stem scar. By contrast, ink applied to dry stem scars remained in a bead and did not penetrate. There was no evidence of ink penetrating the severed columella, which connects fruit to pedicels.

Determination that annular lenticels are infection courts for $\boldsymbol{P}$. carotovorum. During storage of dip- or mist-inoculated tomato fruit, bacterial soft rot lesions formed at edges of the stem scar over junctions of pericarp and endocarp (Fig. 2). The ruptured surface of columella tissues was not clearly infected in any test. Washing inoculated fruit in chlorinated water, as would occur in commercial packinghouses, did not reverse the inoculation even if performed within $1 \mathrm{~h}$ of inoculation (Table 1). If the fruit were stored $18 \mathrm{~h}$ prior to the chlorine wash, bacterial soft rot incidence was not different from that among control fruit. Lesion location was under, at, or adjacent to the stem scar for most (95\%) of the inoculated fruit. In four separate experiments, incidence of bacterial soft rot was greatly reduced if chlorine washes were applied within approximately $2 \mathrm{~min}$ of the inoculation (Table 2). None of the fruit washed within $5 \mathrm{~s}$ developed lesions, whereas 1 of 15,2 of 15,0 of 15 , and 0 of 15 developed lesions if washed within 2 min of inoculation. Stem scars immediately wiped dry with a paper towel after inoculation also failed to become infected.

Effect of storage conditions on development of bacterial soft rot at inoculated lenticels. Upward versus downward orientation of inoculated fruit during storage did not affect decay incidence during three separate tests. Soft rot incidence among fruit stored in the two orientations both averaged $57 \%$ after storage for 5 days. By contrast, only 1 of 60 fruit misted with water alone became diseased. Thus, inoculum was required for high incidences of stem scar infections; moistening the stem scar with water alone did not lead to infection. The RH within the containers that had been lined with wet paper

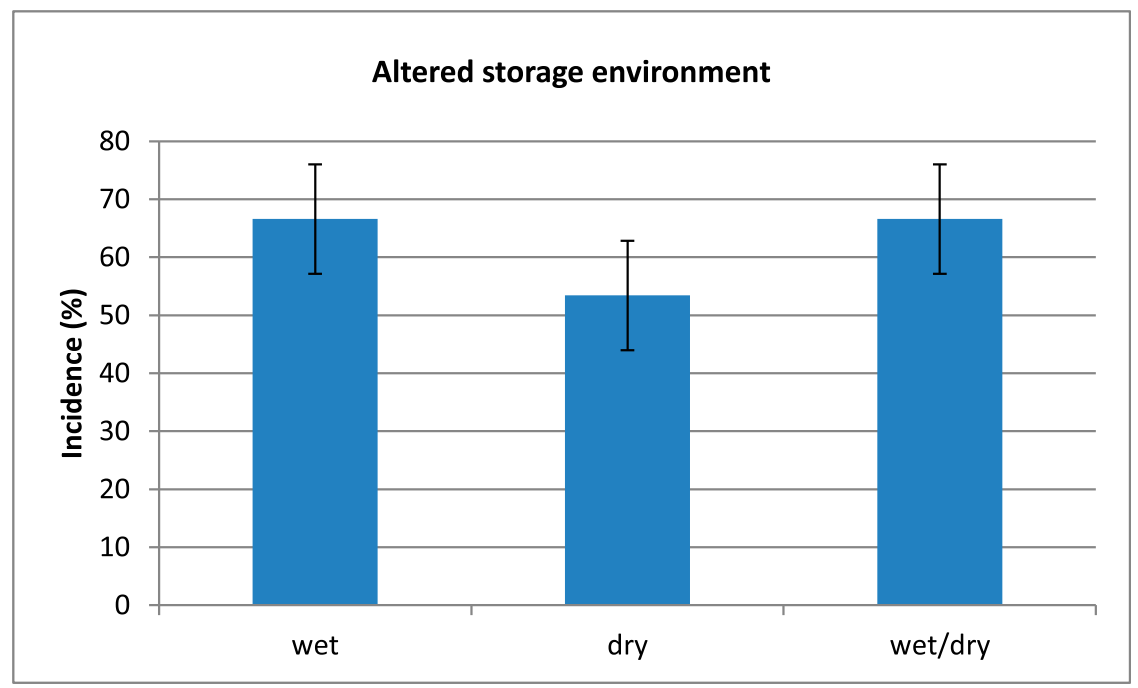

Fig. 3. Incidence of soft rot among tomato fruit held in a latched storage chamber for $48 \mathrm{~h}$ at $24^{\circ} \mathrm{C}$. The fruit had been inoculated by brief immersion in an aqueous suspension of Pectobacterium carotovorum and then placed on a foam depression tray over wet, wet for $24 \mathrm{~h}$ followed by dry, or dry paper towels. 
towels was 88,91 , and $95 \%$ at 1,2 , and $6 \mathrm{~h}$ after container closure, respectively. RH in the containers that were lined with dry towels, were 73,78 , and $88 \%$, respectively, and did not achieve $90 \%$ RH until nearly $9 \mathrm{~h}$. Fifteen fruit were enclosed within each container and represented approximately $63 \%$ of container holding capacity. Lesions were observed within $24 \mathrm{~h}$ and trended lower among fruit stored in the container with the dry paper towels at 48 h (Fig. 3). By 120 h (5 days), however, decay incidence among all three storage regimes was not statistically different and averaged $87 \%$.

Effect of intact calyx on inoculation of annular lenticels. At 2 days after an immersion inoculation, the incidence of bacterial soft rot averaged $67 \%$ among fruit that were stemless versus $7 \%$ of those that had stems at the time of inoculation. By 5 days, $40 \%$ of the latter developed bacterial soft rot versus $93 \%$ of fruit that were stemless at the time of inoculation. In a second experiment with red fruit, by 5 days of storage, $93 \%$ of the stemless fruit had lesions versus $40 \%$ of those with stems $(\operatorname{Pr}>F=0.065)$. In both experiments, approximately half of the lesions on fruit with stems began under the calyx whereas $100 \%$ of lesions among the stemless fruit developed within the stem depression. Thus, an intact calyx provided partial protection against inoculation of stem scar lenticels.

\section{Discussion}

Previous research linked excessive decay development featuring lesion development around the stem scar of tomato fruit with an infiltration of detectable amounts of contaminated water into fruit (Bartz and Showalter 1981). This infiltration was associated with fluid pressures on stem scar surfaces that exceeded internal gas pressures (Bartz 1981). Here, we show extensive bacterial soft rot development following contact of stem scars with inoculum in the absence of detectable infiltration. This is consistent with observations of Wingard (1924) after fruit on plants were inoculated with sections of decayed tissues. Lenticels located in tomato stem depressions (Stahl et al. 2014) are potential infection courts for bacterial soft rot. Lenticel size permits internalization of India ink, which is a stable suspension of carbon particles that has been used in medical research to model suspensions of gram-negative bacteria (Taban et al. 2005). If stem scars are congested with water, such as might occur during wet harvests, particulate matter penetrates within seconds, as predicted from Johnson's work with water-congested leaves (Johnson 1947). Potential routes of suspension movement within fruit include through large intercellular spaces that accompany vascular tissues, as reported by Seaton and Gray (1936).

If stem scars are misted with or dipped into an aqueous cell suspension of $P$. carotovorum, bacterial soft rot develops under this area relatively rapidly and extensively. The presence of a calyx, which loosely covers the stem depression, appears to decrease but not eliminate the potential for bacterial soft rot development. There was no visible evidence that tomato lenticels proliferated as do those on potato tubers (Smith and Ramsey 1947). Adding the water-peptone solution to the stem scar depression per se did not lead to extensive decay because only 1 of 60 fruit moistened with this solution developed a lesion. Storing fruit with stem scar downward on a foam surface would be expected to trap moisture around the stem depression tissues but such an orientation did not affect decay incidence. Washing inoculated stem scars with a chlorine solution reduced but did not reliably prevent decay development, although decay was prevented if inoculated fruit were wiped dry or washed with a chlorine solution within $5 \mathrm{~s}$ after inoculation.
The rapid movement of bacterial soft rot bacteria into lenticels limits grower and packinghouse options concerning controlling decay during unusually wet field conditions. Duration from harvest to washing at a packinghouse ranges from about 4 to $18 \mathrm{~h}$, and wet conditions surrounding fruit during that period greatly exacerbate decay risks if inoculum is present. Hand harvest such that moisture and inoculum do not enter stem scars would limit decay risks but does not appear feasible during a commercial operation. Additionally, contamination by foodborne infectious agents is likely among wet fruit. If the gram-negative $P$. carotovorum can internalize into wet or water congested stem scars, then $S$. enterica could do the same (Bartz et al. 2015b). Moreover it is possible that harmful bacteria could internalize under the calyx during certain weather events in the field or in handling systems where fruit with attached stems are flumed in water that is not properly treated with sanitizers.

\section{Literature Cited}

Bartz, J. A. 1980. Causes of a postharvest loss in a Florida tomato shipment. Plant Dis. 64:934-937.

Bartz, J. A. 1981. Ingress of suspensions of Erwinia carotovora subsp. carotovora into tomato fruit. Pages 452-460 in: Proc. Fifth Int. Conf. Plant Pathol. Bacteriol. Calif. J. C. Lozano, ed. Centro Internacional de Agricultra Tropical. Cali, Colombia.

Bartz, J. A. 1999. Washing fresh fruits and vegetables: Lessons from treatment of tomatoes and potatoes with water. Dairy, Food Environ. Sanit. 19:853-864.

Bartz, J. A., Sargent, S. A., and Scott, J. W. 2015a. Weather fronts and postharvest decays and safety of field-grown tomatoes. Acta Hortic. 1069:333-340.

Bartz, J. A., and Showalter, R. K. 1981. Infiltration of tomatoes by aqueous bacterial suspensions. Phytopathology 71:515-518.

Bartz, J. A., Yuk, H.-G., Mahovic, M. J., Warren, B. R., Sreedharan, A., and Schneider, K. R. 2015b. Internalization of Salmonella enterica by tomato fruit. Food Control 55:141-150.

Brooks, C. 1937. Some effects of waxing tomatoes. Proc. Am. Soc. Hortic. Sci. 35:720.

Clendenning, K. A. 1948. Growth studies of normal and parthenocarpic tomato fruits. Can. J. Res. 26c:507-513.

FDACS. 2011. Food Safety Audit-Tomato Good Agricultural Practices Packinghouse. Florida Department of Agriculture and Consumer Services (FDACS), Division of Fruit and Vegetables.

Gardan, L., Gouy, C., Christen, F., and Samson, R. 2003. Elevation of three subspecies of Pectobacterium carotovorum to species level: Pectobacterium atrospeticum $\mathrm{sp}$ nov., Pectobacterium betavasculorum sp. nov. and Pectobacterium wasabiae sp. nov. Int. J. Syst. Evol. Microbiol. 53:381-391.

Johnson, J. 1947. Water-congestion in plants in relation to disease. Univ. Wis. Res. Bull. 160:1-35.

Pritchard, F. J., and Porte, W. S. 1923. Watery-rot of tomato fruits. A physiological form of Oospora lactis; effect on the host; penetration of the cell walls by enzymatic action. J. Agric. Res. 24:885-906.

Ruehle, G. D. 1940. Bacterial soft rot of potatoes in southern Florida. Fla. Agric. Exp. Stn. Tech. Bull. 348.

Samish, Z., and Etinger-Tulczynska, R. 1963. Distribution of bacteria within the tissue of healthy tomatoes. Appl. Microbiol. 11:7-10.

Seaton, H. L., and Gray, G. F. 1936. Histological study of tissues from greenhouse tomatoes affected by blotchy ripening. J. Agric. Res. 52:217-224.

Smith, M. A. and Ramsey, G. B. 1947. Bacterial lenticel infection of early potatoes. Phytopathology 37:225-242.

Stahl, S. L., Bartz, J. A., Huber, D. J., Spiceland, D., Lee, J. H., and Elkahky, M. T. 2014. An alternative route for bacterial internalization in tomato fruit. (Abstr.) Phytopathology 104:S3.113.

Stahl, S. L., Huber, D., Bartz, J. A., and Lee, J. H. 2015. Visual assessment of gasexchange sites in harvested tomato fruit. (Abstr.) HortScience 50:S13.

Sterlitech Corporation. 2015. Defining a pore size and sterile filtering; 0.2 Microns vs. 0.22 Microns. What's the difference? Online publication. http://www. sterlitech.com/blog/2014/06/26/defining-a-pore-size-and-sterile-filtering-0-2microns-vs-0-22-microns-what $\%$ E2\%80\%99s-the-difference/

Taban, M., Sarayba, M. A., Ignacio, T. S., Behrens, A., and McDonnell, P. J. 2005. Ingress of India Ink into the anterior chamber through sutureless clear corneal cataract wounds. Arch. Ophthalmol. 123:643-648.

Wingard, S. A. 1924. Bacterial soft-rot of tomato. Phytopathology 14:451-459. 